\title{
Human Resource Management Department Development and its Organizational Structures
}

\author{
Lasha Abuladze ${ }^{1, *}$ Zuzana Skorková ${ }^{1}$ \\ ${ }^{1}$ Department of Management, Faculty of Business Management, University of Economics in \\ Bratislava, Slovak Republic, Dolnozemská cesta 1, 85235 Petržalka
}

\begin{abstract}
The purpose of our study represents to determine how HRM's organizational structures has been changed in the past and where HRM is positioned in present. For obtain theoretical knowledge, we used methods: collecting, gathering, sorting, content analysis, synthesis, comparative and deduction of information. Main sources of obtained information, knowledge represent professional articles and research. Today's HRM, its position and roles (strategic partner, administrative expert, change agent, employee champion) has undergone five key stages of evolution, changes in organizational structures. At the early stages, HRM was positioned within different departments, as Labor/administrative manager and Welfare officer with roles: administrative expert and change agent. From later to modern stages (Personnel management, HRM and Modern HRM), HRM, by obtaining new roles (change agent and strategic partner), become mostly complected, complicated and managed to operate as separate department, on the same level of importance as financial, strategic, marketing and other departments within organizational structure. Based on todays trend, linked with HR-to-employee ratio, HR ratio per 100 employees year by year decreases, which might cause another important changes to HR department's position within the organizational structure.
\end{abstract}

\section{Introduction}

Organizational structure is defined as a system that shows how specific activities are designed for achieving, obtaining the goals and objectives of the organization [1]. These activities consist of specific tasks, powers, roles and responsibilities. Organization structure designates formal reporting relationships, including the number of levels in the hierarchy and the span of control of managers and supervisors. Organization structure includes the design of systems to ensure effective communication, coordination and integration of efforts across departments. Through the organizational structure, we can define the way in which information moves and disseminates between different departments within the organizational structure of the company. In a centralized structure, we can recognize that

\footnotetext{
* Corresponding author: lasha.abuladze@euba.sk
} 
decisions move, spread from top to bottom, and vice versa, while in a decentralized structure, decision-making power is divided between different levels of the organization.

Creating and setting an organizational structure allows companies to remain efficient and focused on their objectives [2]. Organizations with variety of sizes shapes make extensive use of organizational structures. They define a specific hierarchy within the organization. A functional and successful organizational structure determines employee's or group of employees' responsibilities, duties, tasks powers and importance. Shortly, the organizational structure shows, underlines who is responsible and what is their responsibility, so the organization can obtain, reach its goals, objectives.

Organizational structures usually have some kind of tall or wide pyramid shape, where most powerful positions are placed on the top of pyramid, while those with the least amount of power are at the bottom. Organizations without formal organizational structure may face difficulties for fulfilling certain activities. For example, employees may have difficulty knowing what responsibilities, power do they have, with whom they have to communicate and report. With help of organizational structure, we can increase efficiency, provide clarity for everyone at every level and make sure, that employees across different departments can be more productive, focused and time efficient.

Human Resource Management - (HRM) represents one of the main parts in today's organizational structures. HRM, alike organizational structure helps organization to reach its goals by effectively managing, motivating, mobilizing and coordinating human resources [3].

Today's HRM, as well as its roles (strategic partner, administrative expert, change agent, employee champion) [5] has undergone number of key changes in organizational structures. HRM's organizational structure also has evolved and changed time by time [6].

In our research we would like to define, determine how HRM's organizational structures has been changed in the past and where HRM is positioned in present. It is important to discuss HRM organizational structure because it is the function's framework, aligning resources with priorities defined in the business strategy and building the organization's culture. The selected organizational structure directly impacts the company's ability to attract, hire, motivate, engage and retain top talent. The demands on human resources function have been changed dramatically in last decades. HRM department is increasingly structured, we are witnessing the emergence of new, specific positions - those are as well defined in our study.

\section{Methods}

For obtain theoretical knowledge, we used the method of collecting, gathering and sorting information. Subsequently, we used method of content analysis of the obtained information, based on which we have selected the most important findings for our research. By using method synthesis, we combined them into one whole and used method induction to draw conclusions. We also used a comparative and deduction methods, i.e. methods of comparing and deducting information and knowledge from several authors. Main sources of obtained information, knowledge represent professional articles and research. Based on the knowledge from the theoretical basis, we defined the current state of the issue.

\section{Results}

\subsection{Evolution of Human Resource Management}


Position of HRM in organizational structures has undergone five major evolutionary stages before its present formation [6]. As we can see on the Figure 1, these five evolutionary stages are: welfare officer, labor manager, personnel management, HRM and modern HRM.

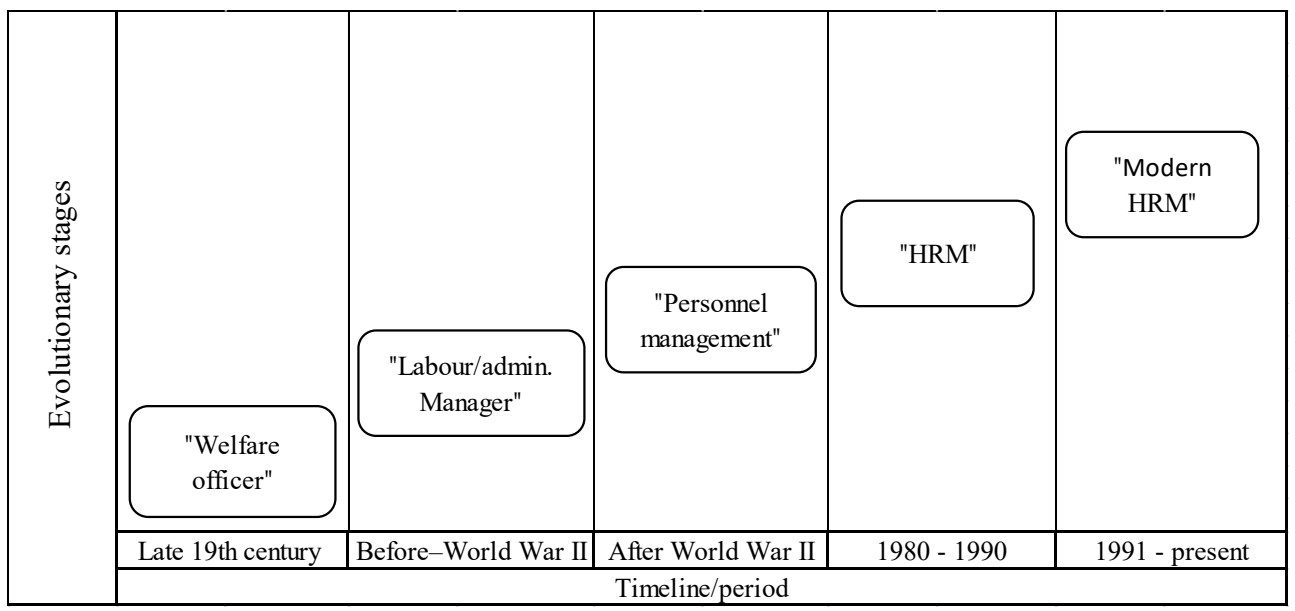

Figure 1. Evolution of Human Resource Management

Source: Own processing

\subsubsection{Welfare officer and its position in the organizational structure}

Between the dates 1890 - 1913, HRM first time emerged as welfare officer in organizational structure [7]. It was the time, when industrial revolution has started booming. Before that time organizations were treating their employee as machine, whose desires, feelings, needs and motives were ignored. Employees used to work 50 hours in a week with possibility to earn few cents per worked hours and without any coffee, relax brakes. Employee discrimination, firing them without any notice or even cause was regular and usual.

After the beginning of the industrial revolution, organizations realized, that the wellbeing and productivity of employees have a mutual relationship. They decreased weekly working hours, offer employees coffee and relax breaks and even started to pay them based on their individual performance. Shortly, organizations started to satisfy very basic and narrow needs of their employees, but they still recognize them as extend of machines.

Primary functions of welfare officer were to hire, fire, discipline, reward employees, policy development and paperwork, which made basement for one of the todays HRM's role - administrative expert with the main goal to create an effective organizational infrastructure within the organization [8]. In the role of administrative expert, welfare workers were responsible for ensuring that the proposed organizational processes were effective and that their successful implementation brings added value to the company. Of course, at that time, welfare worker as administrative expert had very simple form and pretty limited power or influence [9].

In organizational structure, welfare workers were not recognized as a separated department with the same power and importance for organization as financial, operational, strategic and other departments. Welfare workers were represented under financial, operational or administrative departments. 


\subsubsection{Labor/administrative manager and its position in the organizational structure}

The second evolutionary stage of today's HRM is known as evolution Pre-World War II (1914 - 1939). That was the time, when HRM transformed from welfare worker into labor/administrative management. New type of HRM primarily focused on the employees' productivity and started to find proper ways, methods for efficiently using of manpower.

One of the first author who came out with new method, idea of using manpower more efficiently was Frederick W. Taylor, who introduced scientific management. This method, idea still considered employees as some part of machines, who needed scientific training and education in order to fulfil everyday tasks with higher productivity. According to Taylor, there was one best way how to maximize employee productivity and it was scientific way. His theory contributed to HRM new functions: determination of work standards, procedures, individual remuneration, division of labor, scientific selection and employee training [10].

After scientific management emerged another method, ideas how to optimize employee productivity. For example, Henry Fayol published theory of administrative management, which provided HRM new functions focused on organizing, controlling, coordinating and directing. At that time, on the market also emerged another new method called bureaucratic management defined by Max Weber. Bureaucratic management created certain rules, directions, which had to improve employee productivity. According to Max Weber, the ideal organization (bureaucracy) is based on firm standards and formal relationships. This bureaucratic style required from labor/administrative management perfectly knowing rules, directions of their organizations.

New, above mentioned methods were more concentrated on the employees' material, educational, developing and well-being needs than ever before, but despite of all, organizations still greatly were focused on productivity than employees physical or social well-being. Working conditions still continue to be harsh and unfair and governments had very narrow influences on employer/employee relationships. These unsafe, harsh and unfair working conditions forced government to create employer/employee relationship and protecting laws, also first time in history labor unions had established.

As we can see, new stage of evolution brought many changes, new functions to labor/administrative management. During times of labor/administrative management, HRM's role as administrative expert grew near to perfection, also we can see first, very basic shape of role - change agent. At that stage HRM boosted, grew very quickly from welfare worker to labor/administrative management and obtained more important position in organizational structures. Within the organizational structure, despite of its fast growing and increased importance, labor/administrative management still was not considered on the same level as financial, strategic, operational and other departments. Labor/administrative management still used to be positioned within financial, administrative and operational department or was positioned as complementary function.

\subsubsection{Personnel management and its position in the organizational structure}

After World War II (1945 - 1979), today's HRM moved from labor/administrative management into Personnel Management, and it was caused by new emerged behavioral science era. That was the time, when organizations, based on new behavioral theories realized, that in order to increase employees' productivity, only money and material aspects were not enough, but also social and psychological factors needed to be considered and included. Simply, at that time, for organization, employees no more were recognized as part or extend of machines, but as a manpower with their material, non-material, social and psychological needs. These new behavioral notions were proved by Hawthorne study, 
Maslow's theory of needs, Herzberg's two factor theory, McGregor's theory of X and Y and so[11-14].

Post-World War II period (1945 - 1979) is not only known for emerging of behavioral theories, but also for dramatic changes in organizations' external environment. During that time, governments of different nations had started to focus even more on the employee's rights by creating, adopting new employment laws. Also, labour unions were growing and extending with speed of light.

All these new changes, challenges required from personnel management proper adaptation and reaction. During that time HRM as personnel management acquired new, third important role - employee champion, while other roles - administrative expert and change agent - become more complete. That period of time also created safe, fair and positive conditions, atmosphere at workplace. Adaptation on these changes and challenges significantly increased importance of personnel management for organizations and as the result, personnel management was placed as a separated department within the organizational structure, on the same level as financial, strategic, marketing or other departments. Also, we have to mention, that personnel management obtained its new position of organizational structure only in few big, experiment oriented organizations, but generally in most organizations concentration and position remained same until late 20th centuries.

\subsubsection{HRM and its position in the organizational structure}

Between the dates 1980 - 1990 personnel management transformed into human resource management by recognizing employees as most valuable asset and capital of organization. During that time, HRM started to pay even more attention to employees' need for career achievement, development and advancement. HRM also acquired and started using new technologies, EQ, IQ, hard, soft skills and so, through which they tried to concentrate on employees' productivity, well-being, motivation and engagement with the same importance.

Through new look and understanding of manpower, HRM and organization had recognized huge potential and role of human resources as main element, source for creating and obtaining competitive advantage on the market. All these supported to create new, $4^{\text {th }}$ role of HRM - strategic partner [17]. Through this role, the HRM started to connect and align the human resources strategy with the company's business strategy. This means that HR managers became strategic partners by mobilizing, motivating, engaging, coordinating employees for successfully implementing and fulfilling its organizations business strategy. At that time, new HRM role - strategic partner, besides of roles administrative expert, change agent and employee champion, dramatically strengthen importance of HRM for most organizations as well as HRM's position within organizational structure became undoubtable as financial, strategic, marketing and other departments. HRM, as an separate department was positioned on the same level as mentioned ones almost in every type of organizational structures: flat, tall, centralized, decentralized, divisional, matrix and so.

\subsubsection{Modern HRM and its position in the organizational structure}

From 1991 till today, HRM has undergone many internal and external changes as well as acquired variety of new functions based on which modern HRM became more complex than ever. Modern HRM's importance to organization as a strategic partner went to a whole new level by understanding, adopting new trends of: globalization - HRM started to understand the needs, wants and motivations of a diverse and multi-generational-national workforce to attract and retain high-performers and top talents, technological advancement 
and digitalization (industry 4.0)[15,Chyba! Nenašiel sa žiaden zdroj odkazov.] automate much of the work traditionally done by HR professionals. For instance, payroll and streamline the onboarding process, there are also platforms that simplify the recruiting process and talent management systems that enable companies to quickly determine whether their employees are getting the right training opportunities, e-HR; e-training, erecruitment and etc., personnel marketing - retaining and attracting existing or potential employees, organizational culture, ethics, workforce evaluation methods, Human resource planning techniques, flexible work arrangements, virtual teams, work life balance, improved networking; influence of mass media, Greene economy and many others.

All these new changes gave HRM solid position in organizational structures. Nowadays, because of its roles - strategic partner, administrative expert, change agent and employee champion, HRM department has separate position almost in every organizational structure, on the same level as financial, operational, marketing, strategic or other departments. Also, we have to mention, that HRM's recognition and position beside another mentioned department, mostly is caused by its role of strategic partner. Otherwise, HRM might be positioned within production, administrative or financial departments. HRM's position within the organizational structures heavily depends on the following factors too: organization life cycle, business/corporate strategy, state of external environment, size of organization, technology advancement and so.

\subsection{Organizational structure of Human resource department}

The place of HR department in the total organizational structure of the company depends mainly on the size of the company, industry, the speed of change within the industry, and whether or not the responsibilities of HR are sourced internally or externally.

In small organizations, the focus is on company survival, HR practice may appear unstructured and unformalized, there might be no separate HR department, the human resource functions might be carried out by the office manager. According to a report produced by the Cranfield Network on International Human Resource Management [19], $70 \%$ of organizations said HR has a place on the board of directors, and $66 \%$ reported having a written HR management strategy. Responses also indicated that HR is taking sole responsibility for major policy decisions - the more it confirms its position as a strategic partner. Findings of mentioned study pointed out the creation of new positions like Chief Diversity Officer (CDO), Chief Human Resources Officer (CHRO), and changes in who the Vice President of HR or CHRO reports to [20].

For considering the position of HR in organizational structure, we should take into account HR-to employee ratio. This ratio measures the number of HR full-time equivalents (FTEs) for every 100 FTE employees in the organization [21]. Generally, as firms increase in size, the ratio of HR employees to total employees decreases. In a 2015, study of SHRM reported that in small organization (250 or fewer employees) had a significantly higher HRto-employee ratio of 3,4; medium organizations 1,22 and large organizations had ratios of 1,03 [22]. These numbers decrease in time - last study of Workology [23] confirmed, that $\mathrm{HR}$ - to employee ration in small company was 3 , in medium company was 1,2 and only 0,72 in large one.

Historically, several specific positions have developed at HR department. We provide an overview of them in the table 1 . 
Table 1. Positions of HR members by the company size - small (S), medium (M) and large (L)

\begin{tabular}{|c|c|c|c|}
\hline Size & $\mathrm{S}$ & $\mathrm{M}$ & $\mathrm{L}$ \\
\hline HR Ratio & 3 & 1,2 & 0,72 \\
\hline $\begin{array}{l}\text { Chief Human Resources Officer (CHRO) - Responsible for developing } \\
\text { and executing HR strategy in support of the overall business plan and } \\
\text { strategic direction of the organization. Position is aimed specifically on the } \\
\text { areas of succession planning, talent management, change management, } \\
\text { organizational and performance management, training and development, and } \\
\text { compensation. The CHRO provides strategic leadership by articulating HR } \\
\text { needs and plans to the executive management team, shareholders and the } \\
\text { board of directors. } 69 \% \text { of CHROs report directly to CEO [20]. }\end{array}$ & $\mathrm{NO}$ & YES & YES \\
\hline $\begin{array}{l}\text { Vice President of Human Resources (HR) provides executive-level } \\
\text { leadership and guidance to the organizations HR operations. The Vice } \\
\text { President takes responsibility for setting, enforcing, and evaluating legally } \\
\text { compliant human resources policies, procedures, and best practices, and } \\
\text { projecting long-range strategic talent management goals. }\end{array}$ & NO & YES & YES \\
\hline $\begin{array}{l}\text { Chief Diversity Officer (CDO) has responsibility for guiding efforts to } \\
\text { conceptualize, define, assess, nurture, and cultivate diversity as an } \\
\text { institutional and educational resource. Although duties may include } \\
\text { affirmative action/equal employment opportunity, or the constituent needs of } \\
\text { minorities, women, and other bounded social identity groups, chief diversity } \\
\text { officers define their mission as providing point and coordinating leadership } \\
\text { for diversity issues institution-wide [20]. }\end{array}$ & $\mathrm{NO}$ & $\mathrm{NO}$ & YES \\
\hline $\begin{array}{l}\text { HR Business Partner (HRBP) - consultative position, providing resources } \\
\text { and builds relationships while focusing on the strategy, mission, vision and } \\
\text { main objectives of the organization. }\end{array}$ & $\mathrm{NO}$ & $\mathrm{NO}$ & YES \\
\hline $\begin{array}{l}\text { Recruiting Director - senior leader for hiring and recruiting. There are also } \\
\text { other responsibilities - budgeting, allocation, and strategy planning with } \\
\text { senior leadership on talent management. Usually reporting to Vice President } \\
\text { of HR. }\end{array}$ & $\mathrm{NO}$ & YES & YES \\
\hline $\begin{array}{l}\text { HR Director - responsible for the budgets and decisions on financial } \\
\text { investments related HR. It is mostly related on results driving for the } \\
\text { company and less focused on compliance and policy. }\end{array}$ & YES & YES & YES \\
\hline $\begin{array}{l}\text { HR Manager - are responsible for human resources department and they are } \\
\text { insurers of the functions and tasks being carried out by the HR team. They } \\
\text { are the link between employees and an organization's management, as their } \\
\text { work consists of variety of duties - interviewing, and hiring new staff } \\
\text { providing consultation on strategic planning with top executives to } \\
\text { recruiting. }\end{array}$ & YES & $\mathrm{NO}$ & YES \\
\hline $\begin{array}{l}\text { Compensation and Benefits Manager - plans, develops, and oversee } \\
\text { programs to determine how much an organization pays its employees and } \\
\text { how employees are paid. Benefits managers plan, direct, and coordinate } \\
\text { retirement plans, health insurance, and other benefits that an organization } \\
\text { offers its employees. They are also known as remuneration professionals. }\end{array}$ & $\mathrm{NO}$ & YES & YES \\
\hline $\begin{array}{l}\text { HR Specialist - early career human resources professionals who are } \\
\text { specialists providing specific support function or generalists with limited } \\
\text { experience. HR Specialists are focused on administrative tasks - e. g. } \\
\text { payroll, interviewing, employee orientation, training. They can be } \\
\text { specialized in talent management, employee relations, project management, } \\
\text { etc. Large companies have several HR Specialists for these areas. }\end{array}$ & $\mathrm{NO}$ & YES & YES \\
\hline $\begin{array}{l}\text { HR Generalist - covers a wide variety of responsibilities relating HRM - } \\
\text { recruiting and employee relations, handling benefits, compensations, } \\
\text { forecasting and budgeting. }\end{array}$ & $\mathrm{NO}$ & YES & YES \\
\hline $\begin{array}{l}\text { Human Resource Information Specialist (HRIS) - High-tech position, } \\
\text { which is often rather associated with the IT department than with the HR }\end{array}$ & YES & YES & YES \\
\hline
\end{tabular}




\begin{tabular}{|l|l|l|l|}
\hline $\begin{array}{l}\text { department, especially in small companies. HRIS supervises and maintains } \\
\text { HR and recruitment technologies. }\end{array}$ & & \\
\hline $\begin{array}{l}\text { Recruiter - person responsible for recruiting employees - aimed on hiring } \\
\text { and selection for open requisitions. Large companies may have a team of } \\
\text { recruiters, who are dedicated to specific lines of business, functionalities or } \\
\text { regions. }\end{array}$ & YES & YES \\
\hline $\begin{array}{l}\text { Recruiting Coordinator - person responsible for coordinating activities of } \\
\text { other recruiters. More administrative position. }\end{array}$ & YES & YES & YES \\
\hline $\begin{array}{l}\text { HR Coordinator - reporting, processes payroll, events planning and } \\
\text { organizing. }\end{array}$ & YES & YES & YES \\
\hline
\end{tabular}

Source: Own processing.

Organizational structure of HR department should be also considered from the centralization/decentralization point of view. Centralization is the degree to which coordination and control are managed by a core person or level of the organization, usually corporate headquarters. Centralized HR departmental structures help increase efficiency, effectiveness and consistency as well. Half of HR organizations (50\%) are centralized, and very few organizations (15\%) report that they are decentralized [24]. The remaining $35 \%$ use a hybrid model with some decisions and policies deployed commonly across the organization, and some locally. Decentralization is the degree to which decision-making authority and responsibility for coordination and control lies in the sub-units of the firm and individual managers, rather than corporate headquarters or one specific level of the hierarchy. Decentralized model of HR department means that administration and decisions made at the local level. There is a significant variation of policies and practices across field locations. No centralized HR support or administration activities. The last mentioned hybrid model means, that HR department is half centralized and half decentralized.

\section{Conclusion}

The aim of our study was to determine how HRM's organizational structures has been changed in the past and where HRM is positioned in present. Organizational structure is the formal system of tasks and authority relationships that controls how people coordinate their actions and use resources to achieve certain organizational goals and strategy. The organizational structure is used to prevent chaos through an orderly set to reporting relationships and formally set up communication channel. For any organization, the best and appropriate structure is that one, that facilitates effective responses to the problems, facilitates communication and activity coordination. The particular position of HR department in the total organization setup depends on the size of the company. If we talk about small organizations, there might not be any separate HR department and all HR functions will be covered by office manager. In bigger unit, there are HR departments that are structured and aligned with proper business strategy. During the years there were several special positions created for HR department only - Chief Human Resources Officer (CHRO), Vice President of Human Resources (HR), Chief Diversity Officer (CDO), HR Business Partner (HRBP), Recruiting Director, Human Resource Information Specialist (HRIS) and many other. Majority of HR departments are centralized. 


\section{Acknowledgement}

Supported by the Scientific Grant Agency of the Ministry of Education of the Slovak Republic and the Slovak Academy of Sciences VEGA. project No. 1/0412/19 Systems of Human Resources Management in the 4.0 Industry Era.

\section{References}

1. W. Mierzejewska. Directions of changes in organizational structures of SME-results of empirical research. foundations of management 6, 83-92. DOI: 10.1515/fman-20150020 (2014)

2. A. Marjiani, F. T. Ardahaey. The relationship between organizational structure and organizational justice. Asian Social Science 8, DOI:10.5539/ass.v8n4p124 (2012)

3. Y. Yue. Human resource management under enterprise strategic perspective. International Conference on Education, Management and Computing Technology (ICEMCT-14). Atlantis Press. (2014)

4. K. J. Rotich. History, evolution and development of human resource management: a contemporary perspective. Global Journal of Human Resource Management 3, 58-73.

5. N. Sh. Saleh, H. F. Yaacob, M. Sh. Bin Rosli. Critical review: assessing and seeking the intricacy or discrepancy of Ulrich model transforming paradigm in organization human resource. Mediterranean Journal of Social Sciences 6, 324. ISSN 2039-2117 (2015)

6. D. L. Deadrick, D. L. Stone. Human resource management: past, present, and future. Human Resource Management Review 3, 193-195. (2014)

7. T. Ahammad. Personnel management to human resource management (HRM): how HRM functions. Journal of Modern Accounting and Auditing 13, 412-420. DOI: 10.17265/1548-6583/2017.09.004 (2017)

8. J. Lemmergaard. From administrative expert to strategic partner. Employee Relations. DOI : 10.1108/01425450910925328 (2009)

9. R. M. Yusuf, S. Fidyawan, I. S. Wekke. Ulrich model on practices of human resource strategic roles. 2017. https://doi.org/10.31227/osf.io/ysnu8

10. T. Mulcaire. Progressive visions of war in" The Red Badge of Courage" and" The Principles of Scientific Management". American Quarterly 43, 46-72. DOI: 10.2307/2712966 (1991)

11. G. Wickstrom, T. Bendix. The" Hawthorne effect"—what did the original Hawthorne studies actually show?. Scandinavian journal of work, environment \& health, Vol. 26, No. 4: 363-367. (2000)

12. R. J. Taormina, J. H. Gao. Maslow and the motivation hierarchy: measuring satisfaction of the needs. The American journal of psychology 126, 155-177. DOI: 10.5406/126.2.0155 (2013)

13. L. Yaokui. Insight into Herzberg's two-factor incentive theory. 2nd International Conference on Economic Development and Education Management (ICEDEM 2018). Atlantis Press. p. 321-324. (2018)

14. E. Raush, T. L. Russ. Theory $\mathrm{X} / \mathrm{Y}$ assumptions as predictors of managers' propensity for participative decision making. Management Decision. DOI : 10.1108/00251741111130887 (2011) 
15. K. Fettig, et al. Impact of industry 4.0 on organizational structures. In: 2018 IEEE International Conference on Engineering, Technology and Innovation (ICE/ITMC). IEEE, p. 1-8. (2018)

16. S. Shamim, et al. Management approaches for industry 4.0: A human resource management perspective. In: 2016 IEEE Congress on Evolutionary Computation (CEC). IEEE, p. 5309-5316. (2016)

17. C. Sheehan,. A model for HRM strategic integration. Personnel review. DOI: $10.1108 / 00483480510579420$ (2005)

18. SHRM - Society for Human Resource Management. How Organizational Staff Size Influence HR Metrics, online https:/www.shrm.org/ResourcesAndTools/businesssolutions/Documents/Organizational\%20Staff\%20Size.pdf (2015)

19. E. Farndale, M. Vidovic, E. Rockey, Human resource management policies and practices, United States, Cranet, online https://www.shrm.org/hr-today/news/hrmagazine/documents/cranet $\% 20$ reporthr $\% 20$ management $\% 20$ policies $\% 20$ and $\% 20$ prac tices_final.pdf (2015)

20. K. Shellenback, mercer select intelligence, https://www.imercer.com/uploads/Global/hr_structures today.pdf (2017)

21. D. Williams, K. Wade-Golden, The chief diversity officer. CUPA Journal, 58, 38-48 (2007)

22. K. Brustowicz, D. Delano, D. Gabor, B. Salkin, M. Wagner, R. Watson, Mandated Benefits. Compliance Guide (Wolters Kluwer, New York, 2020)

23. J. Miller-Merrell, HR Organizational Chart and Department Structure, Workology, https://workology.com/your-guide-to-the-hr-organizational-chart-and-departmentstructuresstructure-functions/ (2019)

24. E. Farndale, L.H. Hoeksema, J. Paauwe, In-sourcing HR: shared service centres in the Netherlands. International Journal of Human Resource Management 20, 544-561 (2009) 